\title{
Calcium requirements for human sperm function in vitro
}

\author{
Clara I. Marín-Briggiler, Ph.D., ${ }^{a}$ Fernanda Gonzalez-Echeverría, M.Sc., ${ }^{\mathrm{b}}$ \\ Mariano Buffone, M.Sc., ${ }^{\mathrm{C}}$ Juan C. Calamera, Ph.D., ${ }^{\mathrm{c}}$ Jorge G. Tezón, Ph.D., ${ }^{\mathrm{a}}$ and \\ Mónica H. Vazquez-Levin, Ph.D. ${ }^{a}$
}

Instituto de Biología y Medicina Experimental-CONICET-UBA, Fertilab, and Laboratorio de Estudios en Reproducción, Buenos Aires, Argentina

Objective: To determine extracellular calcium $\left(\mathrm{Ca}^{2+}\right)$ requirements for the maintenance of human sperm function in vitro.

Design: Prospective study.

Setting: Basic research laboratory.

Patient(s): Normozoospermic volunteers provided fresh semen samples; follicular fluid (human FF) and oocytes were collected from women undergoing IVF-ET.

Intervention(s): Spermatozoa were incubated for $\leq 18$ hours in media containing different $\mathrm{CaCl}_{2}$ concentrations (maximum, $2.5 \mathrm{mM}$ [control]).

Main Outcome Measure(s): Protein tyrosine phosphorylation patterns, development of hyperactivated motility, induction of the acrosome reaction (AR) in response to human FF, and sperm interaction with homologous zona pellucida (ZP).

Received January 7, 2002; revised and accepted October 24, 2002.

Supported by grants from the World Health

Organization (35 97175), the Agencia Nacional de Promoción de Ciencia y Tecnología (PICT97 00207), and the Consejo Nacional de Investigaciones Científicas y Técnicas (CONICET) of Argentina (PIP 4404).

Presented at the VII International Congress on Andrology, Montréal, Canada, June 15-19, 2001. Reprint requests: Mónica H. Vazquez-Levin, Ph.D., Instituto de Biología y Medicina Experimental, Vuelta de Obligado 2490, (1428) Buenos Aires, Argentina (FAX: 54-11-47862564; E-mail: mhvaz@dna. uba.ar).

a Instituto de Biología y Medicina Experimental, CONICET-UBA.

${ }^{\mathrm{b}}$ Fertilab.

' Laboratorio de Estudios en Reproducción.

$0015-0282 / 03 / \$ 30.00$ doi:10.1016/S0015-0282(03) 00267-X

Result(s): Cells maintained for 18 hours in medium containing $\geq 0.1 \mathrm{mM}$ of $\mathrm{Ca}^{2+}$ were able to undergo the AR when exposed to human FF in the presence of $2.5 \mathrm{mM}$ of $\mathrm{Ca}^{2+}$. Calcium concentrations of $\geq 0.22 \mathrm{mM}$ were sufficient to reach protein tyrosine phosphorylation levels and hyperactivated motility values similar to those of controls. Higher $\mathrm{Ca}^{2+}$ concentrations $(\geq 0.58 \mathrm{mM})$ were required to produce maximum human $\mathrm{FF}-$ induced AR in previously capacitated cells and to obtain an adequate sperm-ZP binding.

Conclusion(s): Different steps of the fertilization process have distinctive $\mathrm{Ca}^{2+}$ requirements. Whereas 0.22 $\mathrm{mM}$ of $\mathrm{Ca}^{2+}$ is sufficient for the development of some capacitation-related events, human FF-induced AR and sperm-ZP interaction require $0.58 \mathrm{mM}$ of this cation. (Fertil Steril ${ }^{\circledR} 2003 ; 79: 1396-403$. @2003 by American Society for Reproductive Medicine.)

Key Words: Acrosome reaction, calcium, capacitation, human spermatozoa, zona pellucida

To acquire fertilization competence, mammalian spermatozoa must reside in the female tract for a certain period of time. After ejaculation, the male gamete must undergo several metabolic and structural changes collectively known as capacitation. This phenomenon has been associated with modifications in plasma membrane composition and fluidity, changes in intracellular ion concentrations, an increase in protein tyrosine phosphorylation, and alterations in the oxidative metabolism. Changes at the flagellum enable spermatozoa to develop hyperactivated motility. In addition, modifications on the sperm head allow the occurrence of the acrosome reaction (AR) in response to an adequate stimuli such as the zona pellucida (ZP) or follicular fluid components (for review, see Yanagimachi [1] and Visconti and Galantino-Homer [2]).

Fertilization-related events can be accomplished in vitro by incubating spermatozoa under specific conditions, which include a defined culture medium. Sperm culture media have been formulated to mimic the complex composition of the oviductal fluid and consist of balanced salt solutions supplemented with appropriate concentrations of electrolytes, metabolic energy sources, and serum albumin. Most culture media include millimolar concentrations of calcium $\left(\mathrm{Ca}^{2+}\right)$ ions. Several reports have indicated that the presence of this cation is required for successful fertilization in vitro (3, 4). However, different events of the fertiliza- 
tion process could have specific $\mathrm{Ca}^{2+}$ requirements, as described in the mouse (4).

Numerous studies have shown the need for extracellular $\mathrm{Ca}^{2+}$ ions for the induction of the AR mediated by physiologic stimuli in all the species studied. An influx of this cation is one of the first events described in the signal transduction cascade leading to the acrosomal loss in response to follicular fluid, progesterone, or ZP (5-9). Contrasting with these observations, there is a report suggesting that $\mathrm{Ca}^{2+}$ influx would not be totally required for $\mathrm{ZP}$ induced AR (10). Regarding $\mathrm{Ca}^{2+}$ requirements for sperm capacitation, although micromolar extracellular concentrations of $\mathrm{Ca}^{2+}$ ions are needed to achieve sperm capacitation in the mouse (4), millimolar concentrations of this cation allow the occurrence of some capacitation-related events in the human $(11,12)$. Concerning sperm interaction with the oocyte, it has been described that spermatozoa from several species require $\mathrm{Ca}^{2+}$ ions to bind and penetrate the ZP (13, 14) and to fuse with the oolemma (4). Nevertheless, specific $\mathrm{Ca}^{2+}$ concentrations needed for human sperm performance in vitro are still unknown.

The objective of the present study was to determine the extracellular $\mathrm{Ca}^{2+}$ concentrations required to accomplish human sperm capacitation, AR, and ZP binding in vitro. Spermatozoa were incubated in the presence of increasing concentrations of $\mathrm{CaCl}_{2}$. Acrosome reaction inducibility in response to human follicular fluid (FF), protein tyrosine phosphorylation levels, development of sperm hyperactivation, and sperm ability to interact with homologous ZP was evaluated.

\section{MATERIALS AND METHODS}

In this study, all human samples used were obtained under donors' written consent, and the protocol was approved by the review board at the Argentine Society of Clinical Investigation.

\section{Culture Media}

The standard medium used throughout the study was human sperm medium (HSM) (15). It consisted of $117.5 \mathrm{mM}$ of $\mathrm{NaCl}, 0.3 \mathrm{mM}$ of $\mathrm{NaH}_{2} \mathrm{PO}_{4}, 8.6 \mathrm{mM}$ of $\mathrm{KCl}, 0.49 \mathrm{mM}$ of $\mathrm{MgCl}_{2}, 2 \mathrm{mM}$ of glucose, $19 \mathrm{mM}$ of sodium lactate, $25 \mathrm{mM}$ of $\mathrm{NaCO}_{3} \mathrm{H}, 0.25 \mathrm{mM}$ of sodium pyruvate, $50 \mu \mathrm{g} / \mathrm{mL}$ of penicillin, and $75 \mu \mathrm{g} / \mathrm{mL}$ of streptomycin. The HSM medium not supplemented with $\mathrm{CaCl}_{2}$ was called $\mathrm{HSM}(-)$. When this medium was supplemented with $2.6 \%$ globulin fatty acid free bovine serum albumin (BSA; Sigma Chemical Co., St. Louis, MO), it contained $0.1 \mathrm{mM}$ of $\mathrm{Ca}^{2+}$, as determined by atomic absorption. To prepare media with increasing $\mathrm{Ca}^{2+}$ concentrations, different amounts of a stock solution of $22.5 \mathrm{mM}$ of $\mathrm{CaCl}_{2}$ were added to $\operatorname{HSM}(-)+$ $2.6 \%$ BSA, giving the following final concentrations of $\mathrm{Ca}^{2+}: 0.22,0.58,1.5$, and $2.5 \mathrm{mM}$. In some experiments, $\mathrm{HSM}$ was supplemented with $2.5 \mathrm{mM}$ of $\mathrm{SrCl}_{2}\left(\mathrm{HSM} \mathrm{Sr}^{2+}\right.$ ).
All of these media had similar osmolarity (308-319 mOsm). Control experiments with $\mathrm{HSM}(-)+0.1 \mathrm{mM}$ of ethyleneglycol-bis( $\beta$-aminoethyl)-N,N,N $\mathrm{N}^{\prime}, \mathrm{N}^{\prime}$-tetraacetic acid (EGTA) were also carried out.

\section{Follicular Fluid Preparation}

Human oocytes were obtained during egg retrieval from women undergoing assisted fertilization, following ovarian stimulation protocols as described elsewhere (16). Follicles were aspirated, and fluids were processed by centrifugation for 15 minutes at $1,500 \times g$ to remove cellular debris. Aliquots from 10 human FF samples were pooled, inactivated by heating at $56^{\circ} \mathrm{C}$ for 30 minutes, filtered through a $0.22-\mu \mathrm{m}$ membrane, and stored at $-20^{\circ} \mathrm{C}$ until further use. Three different pools of human FF were used throughout the study; these proved to be equally capable of inducing a significant increase in the AR.

\section{Semen Samples and Sperm Processing}

Fresh semen samples were obtained from normozoospermic volunteers according to World Health Organization standards (17). In each experiment, ejaculates from different men were used. After complete liquefaction, samples were diluted with $\mathrm{HSM}(-)$ supplemented with $2.6 \%$ BSA and processed by two centrifugations at $300 \times g$ for 10 minutes. Washed spermatozoa were resuspended in the same medium and filtered through glass wool columns (Microfibre Manville, Denver, CO) to recover highly motile cells (18).

Sperm concentration was adjusted to $1.5 \times 10^{6}$ cells $/ \mathrm{mL}$, and $2-\mathrm{mL}$ aliquots were incubated in different media at $37^{\circ} \mathrm{C}, 5 \% \mathrm{CO}_{2}$ in air for different periods of time for up to 18 hours. Postincubation motility was determined by observation under light microscopy $(\times 400$ magnification; Alphaphot-2 YS2, Nikon, Tokyo, Japan) as indicated (17).

\section{Acrosome Reaction Induction}

In the present study, experimental conditions for capacitation were selected according to the protocol described by Calvo et al. (18). These authors demonstrated that the use of globulin-fatty acid free BSA and sperm incubation for $\geq 8$ hours are required to obtain maximal $\mathrm{AR}$ in response to human FF.

To determine minimum $\mathrm{Ca}^{2+}$ requirements for human sperm capacitation, aliquots of $0.75 \times 10^{6}$ spermatozoa were incubated in media containing increasing concentrations of $\mathrm{CaCl}_{2}$ (total $\mathrm{Ca}^{2+}$ concentration from 0.1 to $2.5 \mathrm{mM}$ ). After an 18-hour incubation, appropriate volumes of a $22.5 \mathrm{mM}$ of $\mathrm{CaCl}_{2}$ stock solution were added to reach a final fixed concentration of $2.5 \mathrm{mM}$ of $\mathrm{Ca}^{2+}$, and cells were exposed to $10 \%$ human FF (human FF-induced AR) or buffer (spontaneous $\mathrm{AR}$ ) for 45 minutes at $37^{\circ} \mathrm{C}, 5 \% \mathrm{CO}_{2}$ in air.

To determine $\mathrm{Ca}^{2+}$ concentrations needed to support acrosomal exocytosis, two sets of experiments were carried out. First, cells were incubated in the presence of $0.22 \mathrm{mM}$ of $\mathrm{Ca}^{2+}$ for 18 hours at $37^{\circ} \mathrm{C}, 5 \% \mathrm{CO}_{2}$ in air. Then, the 
suspension was divided into aliquots that were supplemented with different concentrations of $\mathrm{CaCl}_{2}$, and spermatozoa were exposed to human FF or buffer. Spermatozoa that were incubated during the whole period in HSM containing 2.5 $\mathrm{mM}$ of $\mathrm{CaCl}_{2}\left(\mathrm{HSM} \mathrm{Ca}^{2+}\right)$ were included as a control.

In the second set of experiments, spermatozoa were incubated overnight in HSM in which $2.5 \mathrm{mM}$ of $\mathrm{CaCl}_{2}$ was replaced by $2.5 \mathrm{mM}$ of $\mathrm{SrCl}_{2}$, resulting in a condition that allows capacitation but does not support human FF-induced AR (19). After an 18-hour incubation, different volumes of the $\mathrm{CaCl}_{2}$ stock solution were added, and cells were exposed to human FF or buffer. Two aliquots served as controls: spermatozoa maintained for the whole period in HSM containing either $2.5 \mathrm{mM}$ of $\mathrm{SrCl}_{2}\left(\mathrm{HSM} \mathrm{Sr}^{2+}\right)$ or $2.5 \mathrm{mM}$ of $\mathrm{CaCl}_{2}\left(\mathrm{HSM} \mathrm{Ca}{ }^{2+}\right)$.

After the AR induction procedure, spermatozoa were fixed, and the acrosomal status was evaluated by staining with fluorescein isothiocyanate-labeled Pisum sativum agglutinin (Sigma Chemical Co.), as described elsewhere (19).

\section{Detection of Tyrosine-Phosphorylated Proteins}

Proteins from spermatozoa incubated for 4 or 18 hours in media containing different concentrations of $\mathrm{CaCl}_{2}$ were analyzed by sodium dodecyl sulfate-polyacrylamide gel electrophoresis and Western immunoblotting, using a monoclonal antiphosphotyrosine antibody (Upstate Biotechnology Inc., Lake Placid, NY), as described elsewhere (19).

\section{Hyperactivation Analysis}

Spermatozoa were incubated in media containing increasing concentrations of $\mathrm{CaCl}_{2}$ for 4 hours at $37^{\circ} \mathrm{C}, 5 \% \mathrm{CO}_{2}$ in air. The proportion of hyperactivated cells was estimated using an IVOS V10.8s CASA instrument (Hamilton-Thorne Research, Danvers, MA). The settings used during the analysis were as follows: number of frames analyzed per second $=30$, frame rate $=50 \mathrm{~Hz}$, minimum contrast $=85$, minimum cell size $=3$ pixels, and minimum static contrast $=30$. The kinematic values of $\geq 200$ motile spermatozoa were analyzed in each sample, and cells with curvilinear velocity of $\geq 150 \mu \mathrm{m} / \mathrm{s}$, lateral head displacement of $\geq 7 \mu \mathrm{m}$, and linearity of $\leq 50 \%$ were considered hyperactivated (20).

\section{Hemizona Assay}

Human oocytes were obtained during egg retrieval from women undergoing assisted fertilization, following ovarian stimulation protocols as described elsewhere (16). Noninseminated, surplus oocytes were incubated for 6-8 hours in human tubal fluid medium (Irvine Scientific, Santa Ana, CA) for maturation. Cumulus cells were removed by treatment with $80 \mathrm{IU}$ of hyaluronidase (Sigma Chemical Co.) for 20 seconds, followed by washing with phosphate-buffered saline. Oocytes in metaphase II were placed in a 0.1-M Tris (tris[hydroxymethyl]aminomethane), $1.5-\mathrm{M} \quad\left(\mathrm{NH}_{4}\right)_{2} \quad \mathrm{SO}_{4}$, and $0.5 \%$ dextran, $\mathrm{pH} 7$ solution at $4^{\circ} \mathrm{C}$ until use (21).
Twelve hours before performing the hemizona assay (HZA), oocytes were washed four times by pipetting on phosphate-buffered saline and were placed in a Petri dish (BWR Scientific Products, Bridgeport, NJ) at $37^{\circ} \mathrm{C}$. Oocytes were immobilized with holding pipettes (Cook, Queensland, Australia) and bisected into two equal halves using a micromanipulator (Narishigue, Tokyo, Japan) coupled to an inverted microscope (Nikon, Diaphot, Tokyo, Japan). Each hemizona was placed in a $100-\mu \mathrm{L}$ drop of a suspension containing $6 \times 10^{4}$ motile spermatozoa resuspended in the corresponding medium $[\mathrm{HSM}(-)$ and $0.22,0.58$, or $1.5 \mathrm{mM}$ of $\mathrm{Ca}^{2+}$, previously supplemented with $3.5 \%$ BSA. The counterpart hemizona was always incubated with cells resuspended in HSM Ca ${ }^{2+}$ (control hemizona). After a 4-hour incubation, hemizonae were washed by repeated vigorous pipetting, and the number of spermatozoa tightly bound to the outer surface was counted under a $\times 400$ magnification using Hoffman interference optics (Modulation Optics Inc., Greenvale, NY) (22).

\section{Expression of Results and Statistical Analysis}

Data were expressed as mean \pm SE. To assume normal distribution, percentages were converted to ratios and subjected to the arcsine square root transformation. Acrosome reaction results were expressed as AR inducibility (\% human FF-induced AR minus \% spontaneous AR), and HZA data were presented as follows: [1] number of spermatozoa bound per hemizona and [2] hemizona index (= number of spermatozoa bound in the "treated" hemizona [assay performed in the presence of $\leq 1.5 \mathrm{mM}$ of $\left.\mathrm{Ca}^{2+}\right] /$ number of spermatozoa bound in control hemizona [in the presence of HSM $\left.\left.\mathrm{Ca}^{2+}\right]\right)$. Acrosome reaction inducibility and hemizona index values, as well as percentages of hyperactivated spermatozoa, were compared by using Student's $t$ test or one-way ANOVA and Student-Newman-Keuls multiple comparison test. The number of spermatozoa bound in the HZA was compared using the paired Student's $t$ test. Statistical analyses were done with an IBM-compatible computer using the GraphPad InStat program (GraphPad Software, San Diego, CA).

\section{RESULTS}

\section{Calcium Requirements for Human Sperm Capacitation-Related Events}

Sperm ability to undergo acrosomal exocytosis in response to human FF was first used as an indicator of completion of the capacitation process (18). Spermatozoa incubated for 18 hours in $\operatorname{HSM}(-)$ or media containing from 0.22 to $2.5 \mathrm{mM}$ of $\mathrm{Ca}^{2+}$ and then exposed to human FF in the presence of $2.5 \mathrm{mM}$ of $\mathrm{CaCl}_{2}$ showed similar AR inducibility values (Fig. 1).

To further determine whether $\mathrm{Ca}^{2+}$ ions are actually needed for the capacitation process, spermatozoa were incubated for 18 hours in $\operatorname{HSM}(-)$ with or without the addition 


\section{FIGURE 1}

Acrosome reaction inducibility in human spermatozoa preincubated in media with different $\mathrm{Ca}^{2+}$ concentrations. Motile spermatozoa were maintained for 18 hours at $37^{\circ} \mathrm{C}$, in HSM containing different concentrations of $\mathrm{CaCl}_{2}$ (as specified beneath the bars) and exposed for 45 minutes to $10 \%$ human FF (human FF-induced AR) or buffer (spontaneous AR) in the presence of $2.5 \mathrm{mM}$ of $\mathrm{CaCl}_{2}$. Acrosome reaction inducibility was calculated as \% human FF-induced AR minus \% spontaneous AR. Results are expressed as mean $\pm \mathrm{SE}, \mathrm{n}=8$.

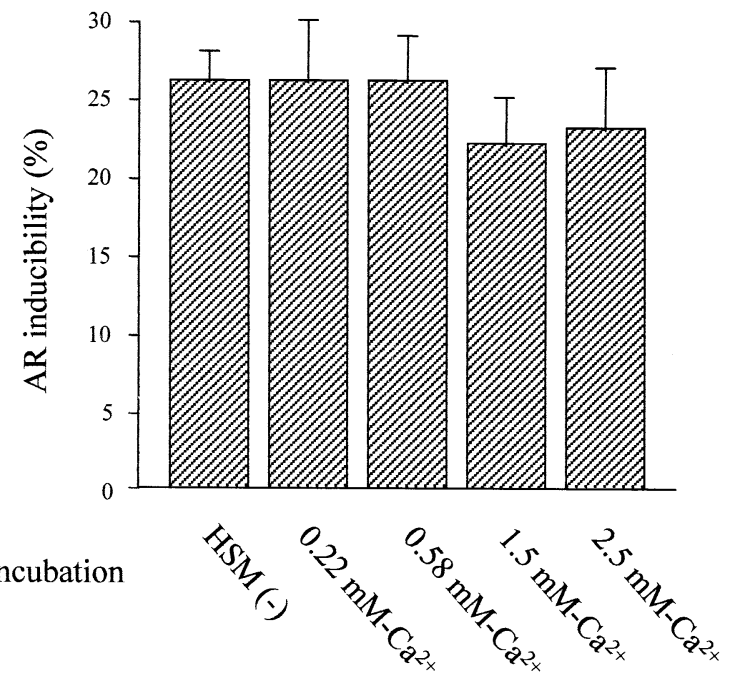

AR induction

$2.5 \mathrm{mM}-\mathrm{Ca}^{2+}$

Marín-Briggiler. Calcium ions and human sperm function. Fertil Steril 2003.

of EGTA $(0.1 \mathrm{mM})$. When the $\mathrm{Ca}^{2+}$ chelator was added to the capacitation medium, AR inducibility was significantly diminished, compared with the case of the control condition $[4 \pm 2 \%$ vs. $26 \pm 1 \%$ for $\operatorname{HSM}(-)+\operatorname{EGTA}$ and $\operatorname{HSM}(-)$, respectively, $P<.001, \mathrm{n}=4]$. These results could not be attributed to a difference in the percentage of spontaneous AR because values were similar in both aliquots $[16 \pm 6 \%$ in $\operatorname{HSM}(-)$ vs. $21 \pm 4 \%$ in $\operatorname{HSM}(-)+$ EGTA]

The requirement of $\mathrm{Ca}^{2+}$ for the occurrence of early capacitation-related events (protein phosphorylation and development of hyperactivated motility) was also examined. The analysis of tyrosine-phosphorylated protein patterns revealed high levels of phosphorylation in spermatozoa maintained for 4 hours in $\operatorname{HSM}(-)$ (Fig. 2, lane A). When cells were incubated in the presence of increasing concentrations of $\mathrm{Ca}^{2+}(\geq 0.22 \mathrm{mM}$ ), a lower signal was found (Fig. 2; compare lane A with lanes B to E). Similar results were obtained in spermatozoa incubated under these conditions for 18 hours (data not shown). Phosphorylation was specific for tyrosine residues, as immunoreactivity was completely abolished when the antibody was previously blocked with $O$-phosphotyrosine (data not shown).

\section{FIGURE 2}

Protein tyrosine phosphorylation patterns in human spermatozoa incubated in media with different $\mathrm{Ca}^{2+}$ concentrations. Motile spermatozoa were resuspended in HSM containing increasing concentrations of $\mathrm{CaCl}_{2}[\mathrm{~A}=\mathrm{HSM}(-)$; $\mathrm{B}=0.22$ $\mathrm{mM}$ of $\mathrm{Ca}^{2+} ; \mathrm{C}=0.58 \mathrm{mM}^{2} \mathrm{Ca}^{2+} ; \mathrm{D}=1.5 \mathrm{mM}^{2} \mathrm{Ca}^{2+} ; \mathrm{E}$ $=2.5 \mathrm{mM}^{\prime} \mathrm{Ca}^{2+}$ ] and incubated for 4 hours at $37^{\circ} \mathrm{C}$. Sperm protein patterns were analyzed by Western immunoblotting using a monoclonal antiphosphotyrosine antibody. Molecular weight markers (MWM) are indicated on the left. A typical experiment is shown. This experiment was performed three times, obtaining similar results.

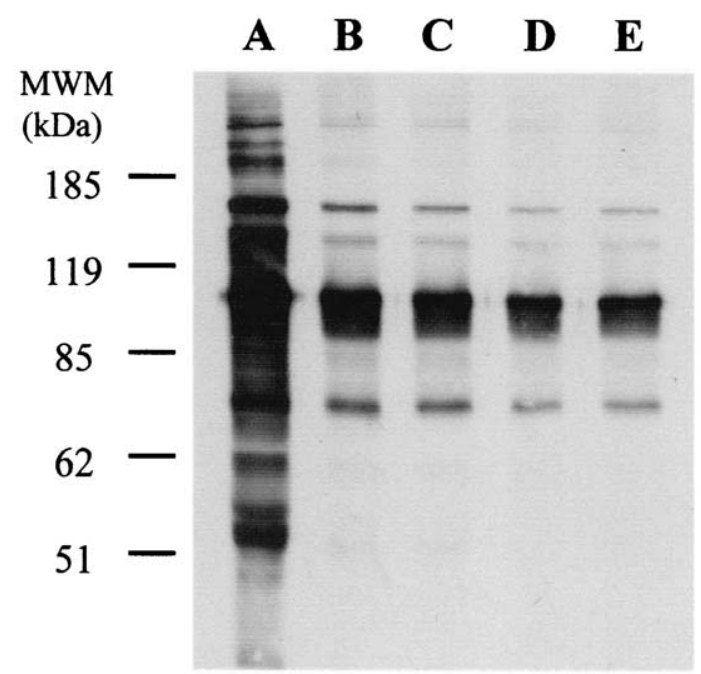

4-h incubation

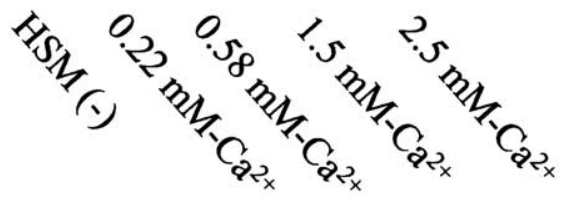

Marín-Briggiler. Calcium ions and human sperm function. Fertil Steril 2003.

The computer-assisted analysis showed negligible percentages of hyperactivated cells $(3 \% \pm 2 \%)$ after 4-hour incubation in medium not supplemented with $\mathrm{CaCl}_{2}$. Conversely, maximum percentages of hyperactivated cells were obtained when spermatozoa were incubated in the presence of $\geq 0.22 \mathrm{mM}$ of $\mathrm{Ca}^{2+}[15 \pm 2 \%$ for $0.22 \mathrm{mM}, 14 \pm 3 \%$ for $0.58 \mathrm{mM}, 14 \pm 2 \%$ for $1.5 \mathrm{mM}, 12 \pm 3 \%$ for $2.5 \mathrm{mM}$ of $\mathrm{Ca}^{2+}, P<.01$ vs. $\left.\operatorname{HSM}(-), \mathrm{n}=4\right]$. This $\mathrm{Ca}^{2+}$ concentration was sufficient for the maintenance of progressive motility after overnight incubation (data not shown).

\section{Calcium Requirements for Human Sperm AR}

To determine the extracellular $\mathrm{Ca}^{2+}$ concentration sufficient to support human sperm AR in response to human FF, cells were first incubated for 18 hours in the presence of 0.22 $\mathrm{mM}$ of $\mathrm{Ca}^{2+}$, and then aliquots were supplemented with different concentrations of $\mathrm{CaCl}_{2}$ before human FF exposure. Figure 3 shows that spermatozoa incubated overnight 
Acrosome reaction inducibility in human spermatozoa exposed to human FF in the presence of different $\mathrm{Ca}^{2+}$ concentration. Motile spermatozoa were incubated for 18 hours at $37^{\circ} \mathrm{C}$ in $\mathrm{HSM}$ containing $0.22 \mathrm{mM}$ of $\mathrm{Ca}^{2+}$ and then exposed for 45 minutes to $10 \%$ human FF (human FF-induced $A R$ ) or buffer (spontaneous AR) in the presence of different concentrations of $\mathrm{CaCl}_{2}$ (as indicated beneath the bars). In a control aliquot, spermatozoa were maintained in HSM supplemented with $2.5 \mathrm{mM}$ of $\mathrm{CaCl}_{2}\left(\mathrm{HSM} \mathrm{Ca}^{2+}\right)$ throughout the experiment. Acrosome reaction inducibility was calculated as $\%$ human FF-induced AR minus \% spontaneous AR. Results are expressed as mean $\pm \mathrm{SE} ; \mathrm{n}=4$. ${ }^{\mathrm{a}} P<.001$ vs. other conditions.

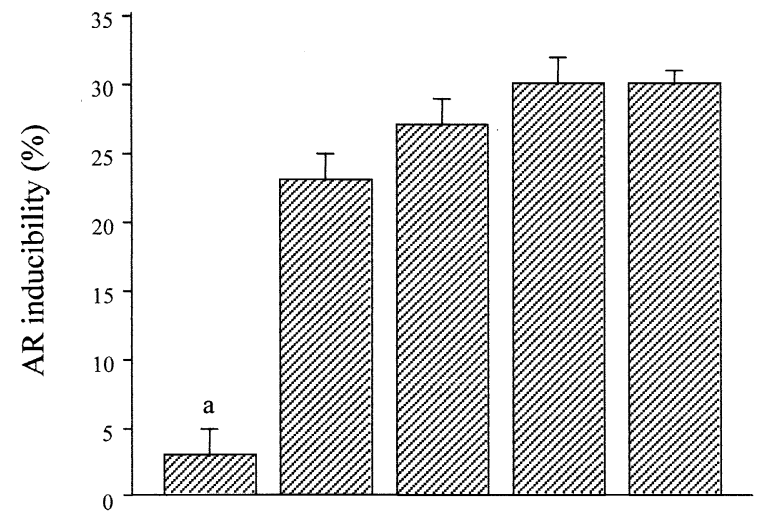

18-h incubation

$0.22 \mathrm{mM}-\mathrm{Ca}^{2+}$

$\mathrm{AR}$ induction

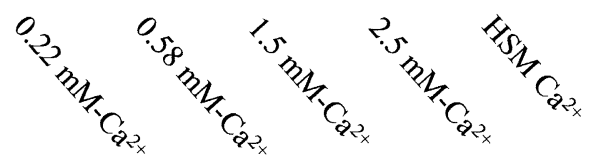

Marín-Briggiler. Calcium ions and human sperm function. Fertil Steril 2003.

and exposed to human FF in the presence of $0.22 \mathrm{mM}$ of $\mathrm{Ca}^{2+}$ were unable to undergo AR. In contrast, cells incubated with human FF in media containing $\mathrm{Ca}^{2+}$ concentrations of $\geq 0.58 \mathrm{mM}$ displayed AR inducibility values similar to those of the control group ( $\mathrm{HSM} \mathrm{Ca}{ }^{2+}$ ).

These results are in agreement with those obtained when spermatozoa were incubated for 18 hours in $\mathrm{HSM} \mathrm{Sr}^{2+}$, followed by exposure to human $\mathrm{FF}$ in the presence of increasing concentrations of $\mathrm{CaCl}_{2}$. Cells treated with human FF in HSM supplemented with $\mathrm{Ca}^{2+}$ concentrations of $\geq 0.58 \mathrm{mM}$ showed an AR inducibility comparable to that of those incubated in $\mathrm{HSM} \mathrm{Ca}^{2+}$ (Fig. 4). These values were significantly higher $(P<.001)$ than those obtained with spermatozoa that were kept in HSM $\mathrm{Sr}^{2+}$ or that were incubated with human FF in the presence of $0.22 \mathrm{mM}$ of $\mathrm{Ca}^{2+}$.

\section{Calcium Requirements for Sperm-ZP Interaction}

To evaluate $\mathrm{Ca}^{2+}$ requirements for human sperm interaction with homologous ZP, the HZA was carried out. When
Acrosome reaction inducibility in human spermatozoa exposed to human FF in the presence of different $\mathrm{Ca}^{2+}$ concentration. Motile spermatozoa were incubated for 18 hours at $37^{\circ} \mathrm{C}$ in $\mathrm{HSM}$ containing $2.5 \mathrm{mM}$ of $\mathrm{SrCl}_{2}$ and then exposed for 45 minutes to $10 \%$ human follicular fluid (human FF-induced AR) or buffer (spontaneous AR) in the presence of different concentrations of $\mathrm{CaCl}_{2}$ (as indicated beneath the bars). In control aliquots, spermatozoa were maintained in $\mathrm{HSM}$ supplemented with either $2.5 \mathrm{mM}$ of $\mathrm{SrCl}_{2}\left(\mathrm{HSM} \mathrm{Sr}^{2+}\right)$ or $2.5 \mathrm{mM}$ of $\mathrm{CaCl}_{2}\left(\mathrm{HSM} \mathrm{Ca}^{2+}\right)$ throughout the experiment. Acrosome reaction inducibility was calculated as \% human FF-induced AR minus \% spontaneous AR. Results are expressed as mean $\pm \mathrm{SE} ; \mathrm{n}=4 .{ }^{\mathrm{a}} \mathrm{P}<.01 \mathrm{vs}$. Other conditions.

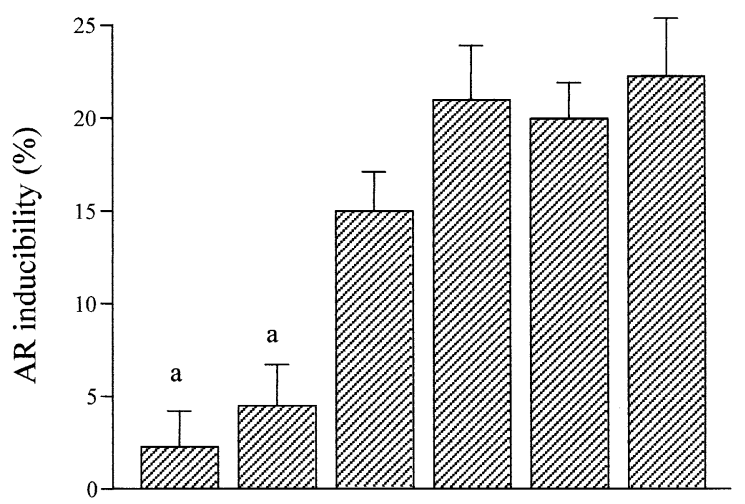

18-h incubation

$\mathrm{HSM} \mathrm{Sr}^{2+}$

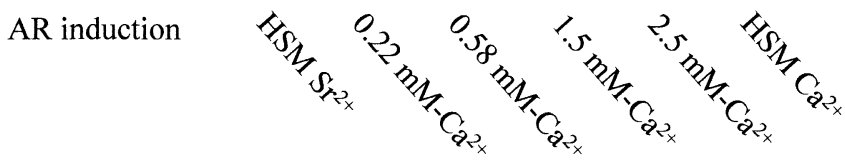

Marín-Briggiler. Calcium ions and human sperm function. Fertil Steril 2003.

the assay was performed either in $\operatorname{HSM}(-)$ or in medium containing $0.22 \mathrm{mM}$ of $\mathrm{Ca}^{2+}$, the number of spermatozoa bound to the hemizona was significantly lower than that in the control $\left[5 \pm 3\right.$ for $\mathrm{HSM}(-)$ vs. $20 \pm 7$ for $\mathrm{HSM} \mathrm{Ca}^{2+}$, $P<.01, \mathrm{n}=5 ; 12 \pm 4$ for $0.22 \mathrm{mM}$ vs. $27 \pm 7$ for HSM $\left.\mathrm{Ca}^{2+}, P<.05, \mathrm{n}=6\right]$. In the presence of $\mathrm{Ca}^{2+}$ concentrations of $\geq 0.58 \mathrm{mM}$, the number of cells bound per hemizona was similar to that in controls $(17 \pm 4 \%$ for $0.58 \mathrm{mM}$ vs. $21 \pm$ 5 for $\mathrm{HSM} \mathrm{Ca}^{2+}, \mathrm{n}=6 ; 15 \pm 8$ for $1.5 \mathrm{mM}$ vs. $14 \pm 7$ for $\left.\mathrm{HSM} \mathrm{Ca}^{2+}, \mathrm{n}=4\right)$. When expressed as hemizona index (Fig. 5), significantly reduced values $(P<.01)$ were obtained with $\mathrm{HSM}(-)$ or $0.22 \mathrm{mM}$ of $\mathrm{Ca}^{2+}$ compared with 0.58 or $1.5 \mathrm{mM}$ of $\mathrm{Ca}^{2+}$.

\section{DISCUSSION}

The present report provides evidence that different aspects of human sperm function in vitro have distinctive extracellular $\mathrm{Ca}^{2+}$ requirements. Although $0.22 \mathrm{mM}$ of $\mathrm{Ca}^{2+}$ ions are needed for the occurrence of several capacitationrelated events, a concentration of $\geq 0.58 \mathrm{mM}$ of this cation is 


\section{FIGURE 5}

Sperm-ZP interaction in the presence of different $\mathrm{Ca}^{2+}$ concentrations. Motile spermatozoa were resuspended in HSM containing different concentrations of $\mathrm{Ca}^{2+}$ (as indicated beneath the bars) and incubated 4 hours, with hemizonae (hemizona) placed in the corresponding medium ("treated" hemizona). Counterpart hemizona was incubated, and the assay was performed in $\mathrm{HSM} \mathrm{Ca}^{2+}$ (control hemizona). Spermatozoa tightly bound to the outer face of each hemizona were counted. Hemizona index was calculated as (number of spermatozoa bound in the "treated" hemizona)/(number of spermatozoa bound in control hemizona). Results are expressed as mean $\pm \mathrm{SE}, \mathrm{n} \geq 4$. ${ }^{\mathrm{a}} P<.01$ vs. 0.58 and $1.5 \mathrm{mM}$ of $\mathrm{Ca}^{2+}$.

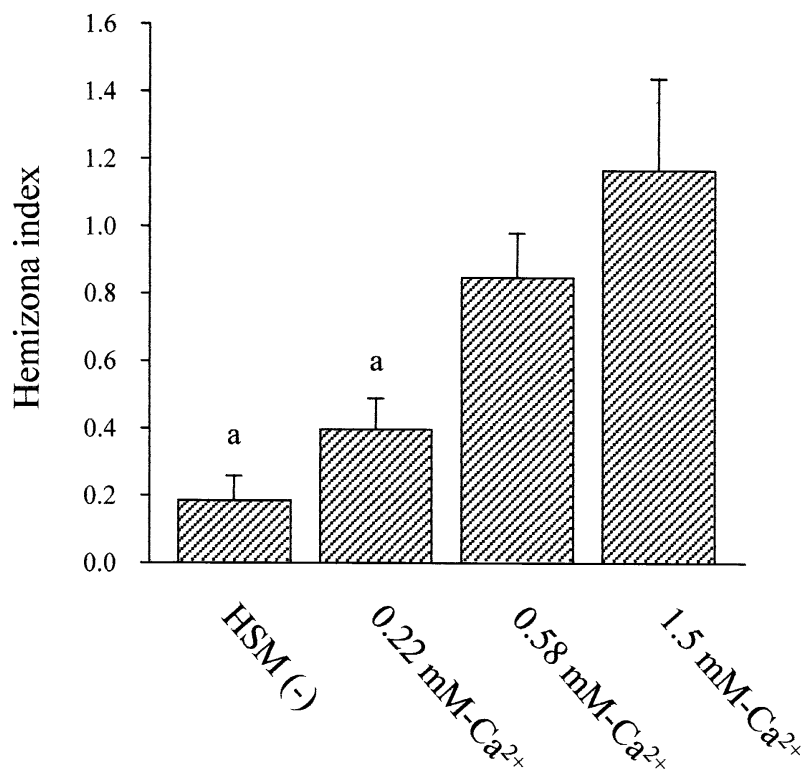

Marín-Briggiler. Calcium ions and human sperm function. Fertil Steril 2003.

required to promote the human $\mathrm{FF}$-induced $\mathrm{AR}$ and to support adequate sperm interaction with homologous ZP.

Previous studies have analyzed $\mathrm{Ca}^{2+}$ requirements for human sperm capacitation by determining the rate of spontaneous AR (11) or by using the chlortetracycline fluorescence assay (12). In the present study, we assessed the need of $\mathrm{Ca}^{2+}$ ions for the occurrence of early events of sperm capacitation (i.e., development of protein tyrosine phosphorylation and hyperactivated motility), as well as for the completion of this process by evaluating the sperm ability to undergo AR in response to human FF. Our results showed that spermatozoa incubated overnight in the presence of 0.1 $\mathrm{mM}$ of $\mathrm{Ca}^{2+}$, that is, $\mathrm{HSM}(-)$, were able to respond to human $\mathrm{FF}$ in medium containing $2.5 \mathrm{mM}$ of $\mathrm{CaCl}_{2}$. Such a low amount of $\mathrm{Ca}^{2+}$ ions appears to be adequate to accomplish sperm capacitation because the addition of EGTA during the 18-hour incubation period prevented the AR, even in the presence of $2.5 \mathrm{mM}$ of $\mathrm{Ca}^{2+}$. However, it cannot be ruled out that a partial sperm capacitation took place in
$\mathrm{HSM}(-)$ and that this process was completed when $2.5 \mathrm{mM}$ of $\mathrm{Ca}^{2+}$ was added during the AR procedure.

The enhancement in protein tyrosine phosphorylation levels observed when spermatozoa were incubated in the presence of low $\mathrm{Ca}^{2+}$ concentrations would support the existence of a down-regulation mechanism mediated by $\mathrm{Ca}^{2+}$, as previously suggested by other investigators (in human: Carrera et al. [23] and Luconi et al. [24]; in boar: Kalab et al. [25]). Such increase in phosphorylation has been attributed to an excessive activity of a tyrosine kinase (24). On the other hand, the lower levels of tyrosine phosphorylation obtained in cells capacitated in media containing high $\mathrm{CaCl}_{2}$ concentrations could result from an activation of a $\mathrm{Ca}^{2+}$ calmodulin-dependent tyrosine phosphatase (23) (see the following paragraphs). These mechanisms would be specie specific, because in other species, such as the mouse, an increase of protein tyrosine phosphorylation is dependent on the presence of $\mathrm{Ca}^{2+}$ ions (26). Considering that human sperm capacitation seems to be associated with a gradual rise in the intracellular $\mathrm{Ca}^{2+}$ concentration (27-29), it is possible that this cation exerts a temporal regulation of the capacitation process by limiting phosphorylation on tyrosine residues.

Some of the proteins phosphorylated on tyrosine residues during capacitation, such as AKAP82 and pro-AKAP82 (23, 30 ), are localized on the sperm flagellum. In addition, the occurrence of tyrosine phosphorylation has been associated with the development of motility and hyperactivation (23, 31 ). Our results showed that cells incubated in medium with $\geq 0.22 \mathrm{mM}$ of $\mathrm{Ca}^{2+}$ ions displayed decreased levels of protein tyrosine phosphorylation, which were accompanied with maximal percentages of progressive motility and hyperactivation. These events might be regulated by a $\mathrm{Ca}^{2+}$ calmodulin-dependent tyrosine phosphatase, known as calcineurin (32), which would be activated in the presence of this amount of $\mathrm{Ca}^{2+}$, maintaining an appropriate level of phosphorylation in proteins involved in sperm motion.

The assessment of minimal extracellular $\mathrm{Ca}^{2+}$ requirements for the induction of the AR revealed that $0.22 \mathrm{mM}$ of $\mathrm{Ca}^{2+}$, a concentration found to support the occurrence of several capacitation-related events, was not sufficient to obtain maximum acrosomal exocytosis in response to the human FF. After overnight incubation in HSM containing this amount of $\mathrm{Ca}^{2+}$ or, alternatively, $2.5 \mathrm{mM}$ of $\mathrm{Sr}^{2+}$, spermatozoa required $\geq 0.58 \mathrm{mM}$ of $\mathrm{Ca}^{2+}$ to reach maximum $\mathrm{AR}$ inducibility levels in the presence of human FF.

When spermatozoa are exposed to $\mathrm{ZP}$, human FF, or progesterone there is a pronounced rise in intracellular $\mathrm{Ca}^{2+}$ concentrations that involves the activation of voltage-dependent $\mathrm{Ca}^{2+}$ channels as well as the release of $\mathrm{Ca}^{2+}$ from intracellular stores (33-36). Considering that a similar intracellular $\mathrm{Ca}^{2+}$ rise (three- to fourfold from basal levels) has been reported after sperm treatment with either human FF or ZP components $(5,7,8)$, it can be speculated that both 
physiologic stimulants might require similar extracellular $\mathrm{Ca}^{2+}$ concentrations to provoke a maximal AR response. A previous report showed that solubilized $\mathrm{ZP}$ is able to partially induce the AR in a medium not supplemented with $\mathrm{Ca}^{2+}$ (10). In the study, however, capacitation was performed in a medium containing $1.3 \mathrm{mM}$ of $\mathrm{Ca}^{2+}$, and actual $\mathrm{Ca}^{2+}$ levels during the AR-induction period were not determined. Remnant $\mathrm{Ca}^{2+}$ ions present in the medium could have been sufficient to support the ZP-induced AR.

Regarding human sperm-oocyte interaction, our results indicate that $0.58 \mathrm{mM}$ of $\mathrm{Ca}^{2+}$ ions are also needed to allow adequate sperm binding to homologous ZP. In the present study, the influence of ZP-induced AR on ZP binding levels under each condition was not evaluated. However, because sperm-ZP binding in $\geq 0.58 \mathrm{mM}$ of $\mathrm{Ca}^{2+}$ was comparable to that found in medium with $2.5 \mathrm{mM}$ of $\mathrm{Ca}^{2+}$, it could be speculated that a similar acrosomal loss may have occurred in both conditions, without affecting gamete interaction.

When the hemizona assay was done in media supplemented with lower $\mathrm{Ca}^{2+}$ concentrations, a significant decrease in the number of cells bound to ZP was observed that could not be attributed to a defective motility. Our results are in agreement with those of a previous report showing that when cells were incubated in a $\mathrm{Ca}^{2+}$-free medium, ZP binding and penetration were negatively affected (14). Calcium requirements for sperm-ZP interaction may differ between species; whereas the presence of these cations is required to support this event in the mouse (13), hamster spermatozoa are able to bind to the $\mathrm{ZP}$ in a $\mathrm{Ca}^{2+}$-deficient medium, even in the presence of EGTA (37). In human and boar, it has been shown that sperm-ZP interaction involves the participation of some $\mathrm{Ca}^{2+}$-dependent molecules, called selectins $(38,39)$. Alternative molecular mechanisms may participate in gamete recognition in other mammalian species and may explain the observed differences in $\mathrm{Ca}^{2+}$ requirements.

An adequate microenvironment plays a fundamental role in gamete function. During their passage toward the site of fertilization, spermatozoa are subjected to variations in the ionic composition of the female genital tract fluids (40). Concerning $\mathrm{Ca}^{2+}$ ions, there are some reports indicating that the human oviductal fluid contains around $1.5 \mathrm{mM}$ of $\mathrm{Ca}^{2+}$ $(41,42)$. Such $\mathrm{Ca}^{2+}$ concentration exceeds those found in this study to be required for sperm function in vitro $(0.22$ $\mathrm{mM}$ for capacitation; $0.58 \mathrm{mM}$ for $\mathrm{ZP}$ interaction and $\mathrm{AR}$, respectively). However, the actual $\mathrm{Ca}^{2+}$ availability in the fertilization milieu is currently unknown.

The results from the present study have shown the $\mathrm{Ca}^{2+}$ requirements for different aspects of human sperm function. These evidences allow the dissociation of some steps of the fertilization process, helping in the understanding of such complex events. The extracellular $\mathrm{Ca}^{2+}$ concentrations required for the development of sperm function in vitro represents approximately $10 \%-20 \%$ of the $\mathrm{Ca}^{2+}$ ions found in standard culture media. Considering that an excess of extra- cellular $\mathrm{Ca}^{2+}$ ions has been shown to accelerate the capacitation process of mouse and human spermatozoa $(4,11,12)$, the findings from this report may be of great clinical relevance. The development of alternative culture media, adapted to the specific ionic needs of the different fertilization steps, may provide a new tool for a better diagnosis and treatment of male infertility, especially for the so-called fast-capacitators patients, who have abnormally accelerated sperm capacitators $(43,44)$.

\section{References}

1. Yanagimachi R. Mammalian fertilization. In: Knobil E, Neill JD, (eds). The physiology of reproduction. New York: Raven: 1994:189-317.

2. Visconti PE, Galantino-Homer HL, Moore GD, Bailey JL, Ning X, Fornes M, et al. The molecular basis of sperm capacitation. J Androl 1998;19:242-8.

3. Yanagimachi R, Usui N. Calcium dependence of the acrosome reaction and activation of guinea pig spermatozoa. Exp Cell Res 1974;89:16174.

4. Fraser LR. Minimum and maximum extracellular $\mathrm{Ca}^{2+}$ requirements during mouse sperm capacitation and fertilization in vitro. J Reprod Fertil 1987;81:77-89.

5. Thomas P, Meizel S. An influx of extracellular calcium is required for initiation of the human sperm acrosome reaction induced by human follicular fluid. Gamete Res 1988;20:397-413.

6. Florman HM, Tombes RM, First NL, Babcock DF. An adhesionassociated agonist from the zona pellucida activates $\mathrm{G}$ protein-promoted elevations of internal $\mathrm{Ca}^{2+}$ and $\mathrm{pH}$ that mediate mammalian sperm acrosomal exocytosis. Dev Biol 1989;135:133-46.

7. Blackmore PF, Beebe SJ, Danforth DR, Alexander N. Progesterone and $17 \alpha$-hydroxyprogesterone. Novel stimulators of calcium influx in human sperm. J Biol Chem 1990;265:1376-80.

8. Brewis IA, Clayton R, Barratt CLR, Hornby DPJ, Moore HD. Recombinant human zona pellucida glycoprotein 3 induces calcium influx and acrosome reaction in human spermatozoa. Mol Hum Reprod 1996;2: 583-9.

9. Breitbart H. Role and regulation of intracellular calcium in acrosomal exocytosis. J Reprod Immunol 2002;53:151-9.

10. Bielfeld P, Anderson RA, Mack SR, De Jonge CJ, Zaneveld LJD. Are capacitation or calcium ion influx required for the human sperm acrosome reaction? Fertil Steril 1994;62:1255-61.

11. Stock CE, Fraser LR. Divalent cations, capacitation and the acrosome reaction in human spermatozoa. J Reprod Fertil 1989;87:463-78.

12. DasGupta S, Mills CL, Fraser LR. $\mathrm{Ca}^{2+}$-related changes in the capacitation state of human spermatozoa assessed by a chlortetracycline fluorescence assay. J Reprod Fertil 1993;99:135-43.

13. Saling PM, Storey BT, Wolf DP. Calcium-dependent binding of mouse epididymal spermatozoa to the zona pellucida. Dev Biol 1978;65:51525.

14. Hoshi K, Tsukikawa S, Sato A. Importance of $\mathrm{Ca}^{2+}, \mathrm{K}^{+}$and glucose in the medium for sperm penetration through the human zona pellucida. Tohoku J Exp Med 1991;165:99-104.

15. Suarez SS, Wolf DP, Meizel S. Induction of the acrosome reaction in human spermatozoa by a fraction of human follicular fluid. Gamete Res 1986;14:107-21.

16. Meldrum DR, Wisot A, Hamilton F, Gutlay AL, Huynh D, Kempton W. Timing of initiation and dose schedule of leuprolide influence the time course of ovarian suppression. Fertil Steril 1988;50:400-2.

17. World Health Organization. Laboratory manual for the examination of human semen and sperm-cervical mucus interaction, 4th ed. New York: Cambridge University Press: 1999.

18. Calvo L, Vantman D, Banks SM, Tezón JG, Koukoulis G, Dennison L, et al. Follicular fluid-induced acrosome reaction distinguishes a subgroup of men with unexplained infertility not identified by semen analysis. Fertil Steril 1989;52:1048-54.

19. Marín-Briggiler CI, Vazquez-Levin M, González Echeverría F, Blaquier JA, Tezón JG, Miranda PV. Strontium supports human sperm capacitation but not follicular fluid-induced acrosome reaction. Biol Reprod 1999;61:673-80.

20. Mortimer ST, Swan MA, Mortimer D. Effect of seminal plasma on capacitation and hyperactivation in human spermatozoa. Hum Reprod 1998; 13:2139-46.

21. Fayrer-Hosken RA, Brackett BG. Use of salt-stored zonae pellucidae for assessing rabbit sperm capacitation for in vitro fertilization. Gamete Res 1987;17:191-201.

22. Burkman LJ, Coddington CC, Franken DR, Kruger TF, Rosenwaks Z Hodgen GD. The hemizona assay (HZA): development of a diagnostic 
test for the binding of human spermatozoa to the human hemizona pellucida to predict fertilization potential. Fertil Steril 1988;49:688-97.

23. Carrera A, Moos J, Ning XP, Gerton GL, Tesarik J, Kopf GS, et al Regulation of protein tyrosine phosphorylation in human sperm by a calcium/calmodulin-dependent mechanism: identification of a kinase anchor proteins as major substrates for tyrosine phosphorylation. Dev Biol 1996;180:284-96.

24. Luconi M, Krausz C, Forti G, Baldi E. Extracellular calcium negatively modulates tyrosine phosphorylation and tyrosine kinase activity during capacitation of human spermatozoa. Biol Reprod 1996;55:207-16.

25. Kalab P, Peknicová J, Geussova G, Moos J. Regulation of protein tyrosine phosphorylation in boar sperm through a cAMP-dependent pathway. Mol Reprod Dev 1998;51:304-14.

26. Visconti PE, Bailey JL, Moore GD, Pan D, Olds-Clarke P, Kopf GS Capacitation of mouse spermatozoa. I. Correlation between the capacitation state and protein tyrosine phosphorylation. Development 1995; 121:1129-37.

27. Irvine DS, Aitken RJ. Measurement of intracellular calcium in human spermatozoa. Gamete Res 1986;15:57-71.

28. Baldi E, Casano R, Falsetti C, Krausz C, Maggi M, Forti G. Intracellular calcium accumulation and responsiveness to progesterone in capacitating human spermatozoa. J Androl 1991;12:323-30.

29. Perry RL, Barratt CL, Warren MA, Cooke ID. Elevating intracellular calcium levels in human sperm using an internal calcium ATPase inhibitor, 2,5-di(tertbutyl) hydroquinone (TBQ), initiates capacitation and the acrosome reaction but only in the presence of extracellular calcium. J Exp Zool 1997;279:291-300.

30. Turner RMO, Johnson LJ, Haig-Ladewig L, Gerton GL, Moss SB. An $\mathrm{X}$-linked gene encodes a major human sperm fibrous sheath protein, hAKAP82. Genomic organization, protein kinase A-RII binding, and distribution of the precursor in the sperm tail. J Biol Chem 1998;273: 32135-41

31. Si Y, Okuno M. Role of tyrosine phosphorylation of flagellar proteins in hamster sperm hyperactivation. Biol Reprod 1999;61:240-6.

32. Tash JS, Krinks M, Patel J, Means RL, Larabi F, Means AR. Identification, characterization, and functional correlation of calmodulin-dependent protein phosphatase in sperm. J Cell Biol 1988;106:1625-33.
33. Arnoult C, Cardullo RA, Lemos JR, Florman HM. Activation of mouse sperm T-type $\mathrm{Ca}^{2+}$ channels by adhesion to the egg zona pellucida Proc Natl Acad Sci USA 1996;93:13004-9.

34. O'Toole C, Arnoult C, Darszon A, Steinhardt RA, Florman HM. $\mathrm{Ca}^{+2}$ entry through store-operated channels in mouse sperm is initiated by egg ZP3 and drives the acrosome reaction. Mol Biol Cell 2000;11: $1571-84$.

35. Shiomi H, Yamano S, Shono M, Aono T. Characteristics of calcium ion influx induced by human follicular fluid in individual human sperm. Arch Androl 1996;37:79-86.

36. Rossato M, Di Virgilio F, Rizzuto R, Galeazzi C, Foresta C. Intracellular calcium store depletion and acrosome reaction in human spermatozoa: role of calcium and plasma membrane potential. Mol Hum Reprod 2001;7:119-28.

37. Yanagimachi R. Requirement of extracellular calcium ions for various stages of fertilization and fertilization related phenomena in the hamster. Gamete Res 1982;5:323-44.

38. Clark GF, Patankar MS, Hinsch KD, Oehninger S. New concepts in human sperm-zona pellucida interaction. Hum Reprod 1995;10(Suppl $1): 31-7$.

39. Geng JG, Raub TJ, Baker CA, Sawada GA, Ma L, Elhammer ÅP Expression of a P-selectin ligand in zona pellucida of porcine oocytes and P-selectin on acrosomal membrane of porcine sperm cells. Potentia implications for their involvement in sperm-egg interactions. J Cell Biol 1997; 137:743-54.

40. Borland RM, Hazra S, Biggers JD, Lechene C. The elemental composition of the environments of the gametes and preimplantation embryo during the initiation of pregnancy. Biol Reprod 1977;16:147-57.

41. Borland RM, Biggers JD, Lechene C, Taymor ML. Elemental composition of fluid in the human fallopian tube. J Reprod Fertil 1980;58: 479-82.

42. Lippes J, Enders RG, Pragay DA, Bartholomew WR. The collection and analysis of human fallopian tubal fluid. Contraception 1972;5:8595

43. Perreault SD, Rogers BJ. Capacitation pattern of human spermatozoa Fertil Steril 1982;38:258-60.

44. Stock CE, Fraser LR. The acrosome reaction in human sperm from men of proven fertility. Hum Reprod 1987;2:109-19. 